\title{
Jacquemontia sandwicensis 'Leeward Community College White', a Versatile Groundcover and Hanging Basket Plant
}

\author{
Orville C. Baldos
}

Department of Tropical Plant and Soil Sciences, University of Hawaii at Manoa, St. John Plant Science Lab 102, 3190 Maile Way, Honolulu, HI 96822

\section{Darel Kenth S. Antesco \\ Institute of Crop Science, University of the Philippines Los Baños, College, Laguna 4031 Philippines}

Additional index words. Convolvulaceae, landscape ground cover, native Hawaiian plant, oval clustervine, pa'uohi'iaka, potted flowering plant

Jacquemontia sandwicensis A. Gray (Convolvulaceae, formerly $J$. ovalifolia subsp. sandwicensis) is a prostrate vine endemic to the main Hawaiian Islands. It typically grows along coastal areas, particularly on the leeward sides of the islands, up to $30 \mathrm{~m}$ above sea level (Wagner et al., 1999). It is a major component of coastal vegetation and is often found growing together with other low-growing species such as Sida fallax (Gagné and Cuddihy, 1990; Richmond and Mueller-Dombois, 1972; Shay and Drake, 2018).

Because of its salt tolerance (Bezona et al., 2009; Elliot and Tamashiro, 2009), year-round flowering (Robertson, 1974; Wagner et al., 1999) and mat-forming growth, it has been used as a native ornamental groundcover in Hawaii. It also has conservation importance because it serves as a pollen and nectar source for the endangered anthricinan yellow-faced bee (Hylaeus anthracinus) (Shay and Drake, 2018). Despite exhibiting diversity in leaf shape, flower color, and stem color, as well as stem and leaf pubescence (Degener and Degener, 1956; Robertson, 1974; Wagner et al., 1999), there has been limited development of $J$. sandwicensis for horticultural selection. Recently, Antesco and Baldos (2020) characterized six accessions of $J$. sandwicensis collected from gardens and wild populations and identified suitable selections for hanging baskets. Here, we describe 'Leeward Community

Received for publication 28 July 2021. Accepted for publication 16 Oct. 2021.

Published online 9 December 2021.

This research was supported in part by the U.S Department of Agriculture (USDA) National Institute of Food and Agriculture (NIFA) Hatch project HAW08040-H, managed by the College of Tropical Agriculture and Human Resources, University of Hawaii at Manoa, and by the Hawaii Department of Agriculture NEWGERMPLASM17 grant.

O.C.B. is the corresponding author. E-mail: obaldos@hawaii.edu.

This is an open access article distributed under the CC BY-NC-ND license (https://creativecommons. org/licenses/by-nc-nd/4.0/).
College White', an Oahu Island selection with glabrous leaves and white flowers.

\section{Origin}

'Leeward Community College White' originated from seeds collected by Alvin Yoshinaga on 19 July 2005 at the Leeward Community College Campus in Pearl City, HI (lat. $21^{\circ} 23^{\prime} 28.5138^{\prime \prime} \mathrm{N}$, long. $-157^{\circ} 59^{\prime} 7$. $\left.2204^{\prime \prime} \mathrm{W}\right)$. Seeds from this collection were used for long-term seed storage and germination studies at the Harold Lyon Arboretum in Honolulu. In May 2016, a seedling from that collection was brought to the University of Hawaii at Manoa's Magoon Research Facility for plant increase (through cutting propagation) and evaluation as a hanging basket plant. From 2017 to 2018, Antesco and Baldos (2020) conducted morphological characterization and hanging basket evaluations of 'Leeward Community College White' and five other accessions. Based on these studies, 'Leeward Community College White' was identified as a promising selection for hanging baskets.

\section{Description}

Descriptions of 'Leeward Community College White' were based on plants evaluated by Antesco and Baldos (2020). Four- to six-node stem cuttings treated with 1000 ppm indole-3-butyric acid were rooted under mist and transplanted into Deepot Cells D40H (volume, $656 \mathrm{~mL}$; Stuewe and Sons, Tangent, OR) filled with a $1: 1 \mathrm{v} / \mathrm{v}$ mix of coconut coir and 1.9-cm-diameter cinder and controlledrelease fertilizer (Nutricote 13-4.8-9.1; Arysta LifeScience) incorporated at $7 \mathrm{~kg} / \mathrm{m}^{3}$. After 1 month, plants were potted in $15-\mathrm{cm}$ (6-inch) pots filled with the same growing medium. Plants were grown for 1 month under full sun and outdoor conditions; they were irrigated daily with an overhead sprinkler $(220 \mathrm{~mL} / \mathrm{d})$. Plants were pruned back $10 \mathrm{~cm}$ from the base of the stem and allowed to regrow for 1 month before characterization.
'Leeward Community College White' has white flowers (N155A; Royal Horticultural Society, 2007) that have an average diameter of $10.5 \mathrm{~mm}$ (Fig. 1). Plants characterized 1 month after pruning have an average of 20 flowers per plant (Antesco and Baldos, 2020). During a separate study, plants potted in 15-cm (6-inch) pots filled with the same growing medium and fertilizer had an average of 22 flowers at 42 and $70 \mathrm{~d}$ after pruning. Capsules 4 to $6 \mathrm{~mm}$ in diameter (Wagner et al., 1999) do not contribute any ornamental value. They are green when immature and turn brown at dehiscence. Leaves of 'Leeward Community College White' are green (144A), glabrous, and broadly elliptic, with an average length of $4.5 \mathrm{~cm}$ and average width of $2.9 \mathrm{~cm}$. Stems are purple (N77A) and have medium pubescence.

'Leeward Community College White' is ideal for containerized applications because of the short internode lengths of its stems (average length, $1.6 \mathrm{~cm}$ ). It also exhibits a high number of lateral branches per plant (14 branches per plant 1 month after pruning) in contrast to other accessions tested by Antesco and Baldos (2020).

\section{Propagation}

'Leeward Community College White' is easily propagated using four- to six-node vine cuttings with leaves and preformed root initials or through simple or compound (serpentine) layering. The application of rooting hormone is not required (Bornhorst, 2005) because preformed roots are already present. Cuttings can be rooted under mist ( $10 \mathrm{~s}$ every

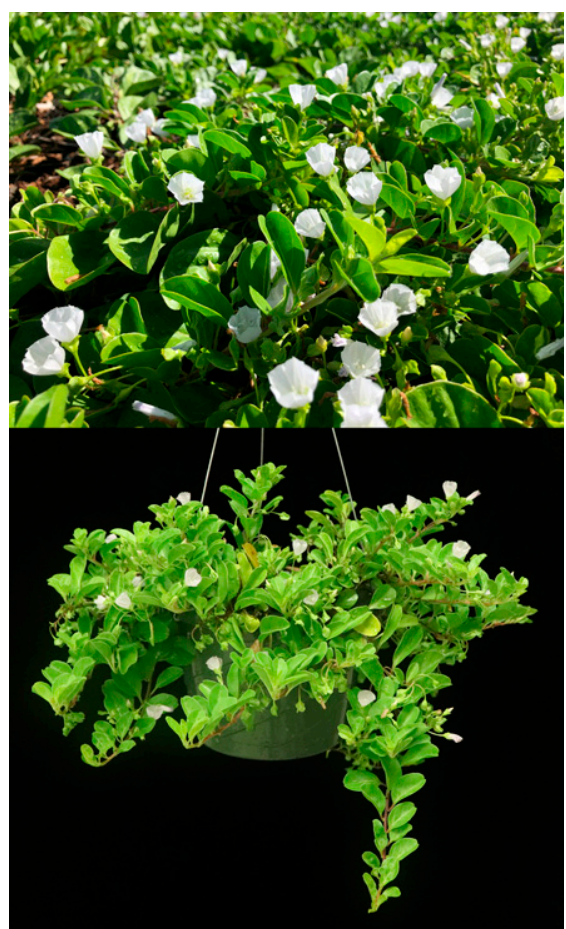

Fig. 1. Jacquemontia sandwicensis 'Leeward Community College White' used as a landscape groundcover (top) and as a potted plant in a $20-\mathrm{cm}$ ( 8 -inch) hanging basket (bottom). 
$6 \mathrm{~min}$ ) for $21 \mathrm{~d}$ in a $1: 1 \mathrm{v} / \mathrm{v}$ mix of perlite and vermiculite before potting in the final growing medium. Propagating under these conditions can result in $84 \%$ rooting (Antesco, 2019). In addition to rooting under mist, cuttings can be directly planted in the final potting medium (e.g., 3 cuttings $/ 20 \mathrm{~cm}$ pot) if the potting mix is moist and the pots are kept under shade until plants have rooted.

\section{Availability}

'Leeward Community College White' is available to interested nurseries in Hawaii. Contact Orville Baldos (e-mail: obaldos@hawaii.edu) for inquiries.

\section{Literature Cited}

Antesco, D.K.S. 2019. Characterization and propagation of pa'uohi'iaka (Jacquemontia sandwicensis A. Gray) for potential use as a hanging basket plant. Univ. of Hawai' $i$ at Manoa,
Honolulu, MS thesis. 20 July 2021. <http:// hdl.handle.net $/ 10125 / 63270>$.

Antesco, D.K.S. and O.C. Baldos. 2020. Morphological characterization and identification of Jacquemontia sandwicensis A. Gray (Pa'uohi'iaka) accessions for hanging basket use. Genet. Resources Crop Evol. 67:1919-1928, https:// doi.org/10.1007/s10722-020-00951-2.

Bezona, N., D. Hensley, J. Yogi, J. Tavares, F. Rauch, R. Iwata, M. Kellison, M. Wong, and P. Clifford. 2009. Salt and wind tolerance of landscape plants for Hawai' $i$. Univ. of Hawai ${ }^{i} i$ at Manoa College of Trop. Agr. and Human Resources Coop. Ext. Serv. 20 July 2021. $<$ http://hdl.handle.net/10125/12324>.

Bornhorst, H.L. 2005. Growing native Hawaiian plants: A how-to guide for the gardener. Bess Press, Honolulu, HI

Degener, O. and I. Degener. 1956. Jacquemontia sandwicensis. Flora hawaiiensis book 5: New illustrated flora of the Hawaiian Islands. O. Degener, Honolulu, HI.

Elliot, D.D. and S.Y. Tamashiro. 2009. Native Plants Hawaii: Jacquemontia sandwicensis. 20
July 2021. <http://nativeplants.hawaii.edu/plant/ view/jacquemontia_sandwicensis $>$.

Gagné, W.C. and L.W. Cuddihy. 1990. Vegetation, p. 45-114. In: W.L. Wagner, D.R. Herbst and S.H. Sohmer (eds.). Manual of the flowering plants of Hawai'i. Univ. of Hawai'i Press, Honolulu, HI.

Richmond, T.A. and D. Mueller-Dombois. 1972. Coastline ecosystems on O'ahu, Hawai' i. Vegetatio 25:367-400, https://doi.org/10.1007/BF00 452982.

Robertson, K. 1974. Jacquemontia ovalifolia (Convolvulaceae) in Africa, North America, and the Hawaiian Islands. Ann. Mo. Bot. Gard. 61(2):502-513, https://doi.org/10.2307/2395073.

Royal Horticultural Society. 2007. Royal Horticultural Society colour chart. RHS, London, UK.

Shay, K.R. and D.R. Drake. 2018. Pollination biology of the Hawaiian coastal vine Jacquemontia sandwicensis (Convolvulaceae). Pac. Sci. 72(4): 485-499, https://doi.org/10.2984/72.4.8.

Wagner, W., D. Herbst, and S.H. Sohmer. 1999. Manual of the flowering plants of Hawaii. Revised ed. Univ. of Hawai' i Press, Honolulu, HI. 